Article

\title{
THE DOMAIN OF DISTRIBUTIVE JUSTICE: PERSONAL CHOICES, INSTITUTIONS, STATES OF AFFAIRS
}

\author{
ALISTAIR M. MACLEOD \\ Department of Philosophy, Queen's University. Kingston, Canada. ${ }^{1}$
}

\begin{abstract}
This article examines G.A. Cohen's celebrated critique of the Rawlsian doctrine of "the basic structure as subject." Cohen describes the principal difference between his and Rawls's view of "the site of distributive justice" that is, of "the sorts of items to which principles of distributive justice apply" by claiming that whereas in his view "both just rules and just personal choice within the framework set by just rules are necessary for distributive justice," the Rawlsian view is that "distributive justice and injustice are features of the rules of the public order alone." Despite the acuteness of Cohen's criticisms of the Rawlsian positions he targets, there are important strands in Rawls's view of the domain within which judgments of distributive justice can be made that are not adequately reflected in these positions. When these ambiguities in Rawls's writings are given due weight, it emerges that the similarities between the views Rawls and Cohen take of the task of a theory of distributive justice are more striking than the differences. The only major difference, arguably, concerns the status of judgments about the "personal choices" the members of a society must make when their options are unconstrained by just institutional rules - that is, when the alternatives they can opt for are neither required nor prohibited by
\end{abstract}

\footnotetext{
1 Alistair Macleod is Professor Emeritus of Philosophy at Queen's University, where he served as Department Head from 1986 to 2000. He currently teaches in the graduate program, principally in Moral and Political Philosophy. Among his publications are a short book, Social Justice, Progressive Politics and Taxes (2004) and papers on liberty, equality, justice, democracy, efficiency and rationality in a variety of collections and in such philosophical periodicals as The Journal of Philosophy, The Canadian Journal of Philosophy, Hume Studies, The Journal of Social Philosophy, and Archiv fur Rechts- und Sozialphilosophie. He was the President of the North American Society for Social Philosophy (NASSP) from 2005 to 2010.
}

Alistair MacLeod est professeur émérite de philosophie à Queen's University, où il a servi comme directeur du département de 1986 à 2000. Actuellement, il enseigne dans le programme doctoral, principalement en philosophie morale et politique. Parmi ses publications figurent un court livre, Social Justice, Progressive Politics and Taxes (2004) et de nombreux articles sur la liberté, l'égalité, la justice, la démocratie, et la rationalité dans une variété de collections et dans des revues philosophiques telles que The Journal of Philosophy, The Canadian Journal of Philosophy, Hume Studies, The Journal of Social Philosophy, et Archiv fur Rechts- und Sozialphilosophie. Il a présidé la société nord américaine de philosophie sociale (NASSP) de 2005 à 2010. 
these rules. For Rawls these are choices they are at liberty to make in any way they please. According to Cohen, however, at least some of these choices must be made by direct appeal to the principles of distributive justice that underpin just institutional rules.

\section{Résumé}

Cet article analyse la critique justement célèbre par G.A. Cohen's de la doctrine de Rawls concernant "la structure de base comme sujet». Cohen décrit la différence principale entre son point de vue et celui de Rawls sur «le lieu de la justice distributive " -- c'est à dire les "types d'objets auxquels les principes de justice distributive s'appliquent "-- en soulignant que, tandis que pour lui, «les règles justes et les choix personnels justes dans le cadre de règles justes sont nécessaires pour la justice distributive", pour Rawls "la justice distributive et l'injustice sont des résultantes des seules règles d'ordre public ". Malgré la pertinence de la critique par Cohen de cette position de Rawls, certaines réflexions de Rawls quant au domaine de validité des jugements de justice distributive ne s'y conforment pas pleinement. Quand ces ambigüités des écrits de Rawls sont évaluées à leur juste mesure, il émerge que les similarités entre les visions que de Rawls et de Cohen sur les enjeux d'une théorie de la justice distributive sont plus frappantes que les différences. La seule différence majeure, peut-être, concerne le statut des jugements à propos des « choix personnels " que les membres d'une société doivent prendre quand ces options ne sont pas contraintes par des règles institutionnelles justes - c'est à dire, quand les alternatives parmi lesquelles ils peuvent choisir ne sont ni requises ni interdites par ces règles. Pour Rawls, ce sont des choix qu'ils sont libres de faire comme il leur plait. Chez Cohen, en revanche, certains de ces choix au moins nécessitent de se référer directement aux principes de justice distributive qui sous-tendent des règles institutionnelles justes.

\section{Key words}

distributive justice; institutional outcomes; institutional rules; personal choices; procedural justice.

\section{Mots-clés}

choix personnels; justice distributive; justice procédurale; règles institutionnelles; résultats institutionnels;

Autobiographical passages in Cohen's publications and interviews confirm that his commitment to social equality has been a constant feature of his moral, political, and philosophical outlook through the several (in many ways strikingly different) phases of his career. Instilled in him by his early upbringing in a communist household in Montreal, this commitment provided part of the inspiration when, as an "analytical" Marxist, he tried to rid Marxism of its attachment to historical materialism, and it provided the driving force behind his long engagement, in a later period, with Nozickian libertarianism. In the final decade of his life, it was the impetus to his impressively detailed critique of Rawlsian doctrines, enabling him to refine his distinctive version of a 
doctrine of egalitarian justice. In the last book published during his lifetime - the awardwinning Rescuing Justice and Equality - sparring with Rawls allowed him to "rescue" both justice and equality from the embrace of those liberal egalitarians with whom he still had disagreements.

However, the overlap between Cohen's final positions and those he attributes to Rawls is extensive - particularly if his potentially controversial exegetical claims about the Rawlsian corpus can be successfully challenged. On central issues of distributive justice for example, about the role of incentive-providing schemes in generating unjust economic inequalities - the differences are evident enough on the surface. However, despite Cohen's acute expository skills, doubts can be entertained about how deep the disagreements run, partly because of uncertainty about how the role played by the Difference Principle in the Rawlsian doctrine of "justice as fairness" is to be characterized. On the question of the boundaries and contours of the domain within which debates about the content of a doctrine of distributive justice must be conducted - concerning the many different subjects about which judgments of distributive justice can be made and the logical relationships that obtain between judgments of these different kinds - there is also a good deal of surface disagreement between Cohen and Rawls. In his 1997 article in Philosophy and Public Affairs ("The Site of Distributive Justice"), and both in his Gifford Lectures (published in 2000 under the title If You're an Egalitarian, How Come You're So Rich?) and in Rescuing Justice and Equality (2008), Cohen elaborately critiques the Rawlsian doctrine of "the basic structure as subject" that ostensibly forms the core of Rawls's view of the kinds of judgments of distributive justice his own theory of "justice as fairness" is designed to illumine.

While this doctrine can plausibly be represented as forming an important part of the backdrop to Rawls's substantive theory of "justice as fairness," the issues it raises are more conceptual or methodological than expressly normative. It purports to identify the kinds of things (the "subjects") of which justice and injustice can intelligibly be predicated when judgments of distributive justice are made but it provides no answers to expressly normative questions about whether these judgments can be justified or about the principles under which these judgments can be subsumed when they are justifiable. Rawls's view of the domain within which judgments of distributive justice can be made and of the logical interconnections between these judgments - could consequently be accepted by those who disagree with the substance of his account of distributive justice. Differences of view about the domain of distributive justice ought to be resolvable independently of resolution of substantive disagreements about the content of a doctrine of distributive justice. Indeed, substantive disagreements can only be perspicuously articulated if it's clear what the questions are to which judgments of distributive justice provide possible answers. Thus if it's agreed that social institutions -- legal, political, economic, etc. -- can be characterized as "just" or "unjust," disagreements about whether, 
in given circumstances, this or that institution (and the rules governing its operation) should be said to be just or unjust (and related disagreements, at a higher level of generality, about the principles that underpin defensible judgments about the justice or injustice of institutional arrangements) can at least be clearly stated.

Without denying that Cohen's substantive views about justice and equality are at odds in some important respects with the substance of Rawls's (“justice as fairness") account of egalitarian justice -- and while skirting questions about what these differences amount to -- I want to explore the differences Cohen claims there are between their respective views of the domain of distributive justice. ${ }^{2}$

In one central criticism Cohen directs at Rawls's view of the domain within which questions of justice arise, ${ }^{3}$ he takes issue with the doctrine that the primary subject of judgments of justice is the "basic structure" of society. According to Cohen, "egalitarian justice is not only, as Rawlsian liberalism teaches, a matter of the rules that define the structure of society, but also a matter of personal attitude and choice." He describes the principal difference between his and Rawls's view of "the site of distributive justice" that is, of "the sorts of items to which principles of distributive justice apply" - by claiming that whereas in his view "both just rules and just personal choice within the framework set by just rules are necessary for distributive justice," the Rawlsian view is that "distributive justice and injustice are features of the rules of the public order alone." My aim is to explore Cohen's critique of what Rawls has to say about the domain of distributive justice and show that the similarities between their views are more striking than the differences. If their views converge more than they diverge, the explanation is neither that Cohen's objections to the positions he criticizes are ineffective nor that these positions cannot plausibly be attributed to Rawls. Rather, the explanation is that there are scattered strands in Rawls's writings that commit him to positions that are at no great

\footnotetext{
${ }^{2}$ Since Cohen's sudden death on August 5, 2009 means that we can no longer look forward to his always acute and memorable responses to critiques of his work, it is more important than ever for interpreters and critics of his assessments of Rawlsian doctrines not to misrepresent his views. I would like to record that, in a graduate seminar at Queen's University during his week-long visit to the Philosophy Department only months before his death, he indicated, in response to the informal presentation of a version of this manuscript, that he agreed that in his view judgments about the justice of institutional outcomes are more fundamental than judgments about the justice of institutional rules -- and that the sharpness of his disagreement with the Rawlsian doctrine of the "basic structure as subject" is diminished if Rawls's principles of "justice as fairness" can be seen (as he agreed they can) as having their primary application to the states of affairs brought about by the institutions that belong to the "basic structure" and as applying only derivatively to the institutions themselves.

${ }^{3}$ G.A. Cohen, Rescuing Justice and Equality (Harvard University Press, 2008), pp. 125-126. See also If You're An Egalitarian, How Come You're So Rich? (Harvard University Press, 2000) and "Where the Action Is: On the Site of Distributive Justice" (Philosophy and Public Affairs, 26, 1997, pp. 3-30).

${ }^{4}$ If You're an Egalitarian, How Come You're So Rich, $\mathrm{x}$

${ }^{5}$ op cit, pp. 3-4
} 
distance from those Cohen favors despite the fact that these positions are at variance with some of Rawls's most familiar expressed views.

\section{Two Questions}

Two questions need to be distinguished if the crucial differences between Rawls and Cohen about the domain of distributive justice are to be pinpointed. The first is about the boundaries within which judgments governed by principles of distributive justice are made. The key concern here is whether judgments of this or that sort - for example, about the everyday conduct of individuals - should be allowed to count as judgments of justice, and if so, under what conditions. The second is about the relations that obtain between judgments of the various kinds that fall within the domain of justice. The important issue here is the interpretation and assessment of Rawls's well-known claim that judgments about institutions (particularly those that form what he calls "the basic structure" of society) enjoy a certain "primacy" in relation to other judgments of justice.

Both questions require attentiveness to diversity in the judgments to which principles of distributive justice are applicable, particularly diversity in the subjects of judgments of justice. But the focus differs. In the first question, the focus is on whether a judgment of this or that kind -about the choices individuals make, or the rules that give structure to institutional arrangements, or the states of affairs that eventuate, whether from the choices of individuals or from the workings of institutions (or both) - should count as a judgment of justice. In the second, the focus is on the logical relations that obtain between judgments of justice of different kinds, particularly on whether any of these (judgments about institutions, for example, to cite those Rawls represents as "primary") are logically more fundamental than the rest.

On the boundaries of the domain of distributive justice, at least three issues need to be clarified (whether in Rawls's position as he propounds it, or as Cohen conceives it). (1) Are the institutions that for Rawls constitute the "primary" subjects of judgments of distributive justice institutions governed by rules that impose legally enforceable obligations? Cohen attacks Rawls's doctrine of the "basic structure as subject" partly on the ground that Rawls collapses "basic structure" into the "legally coercive" structure. (2) Does Rawls exclude from the domain judgments about the conduct of individuals, including "personal choices" made by people in everyday life? (3) Do judgments about states of affairs - brought about by the implementation of institutional rules, for example - fall within the domain of distributive justice?

Regarding the logical relations that obtain among judgments of the various sorts that 'count' as judgments of distributive justice a number of issues can be identified. Some clarify Rawls's view of the domain of justice, others clarify Cohen's critique of Rawls. (a) One central issue is the relationship between judgments about institutional 
rules and judgments about individual conduct. (b) A second, more sharply relevant for Cohen than for Rawls, is the relationship between judgments about the justice of people's everyday "personal choices" (especially those Cohen identifies as being made "within" the rules of the basic structure, where these are choices he regards - unlike Rawls -as governed by principles of distributive justice) and judgments about the states of affairs that result from these choices. (c) A third is the relationship in which judgments about the justice of institutions (and institutional rules) stand to judgments about the states of affairs that eventuate from the workings of institutions.

Both sets of questions will be taken up, some briefly, some in detail, in what follows. ${ }^{6}$

\section{The Rawlsian "Basic Structure" and the "Legally Coercive Structure"}

Cohen claims that Rawls conceives of the domain of distributive justice too narrowly by representing all judgments of justice as judgments about a society's "basic structure" and then conceiving of the "basic structure" itself too narrowly. He claims that Rawls restricts institutions that belong to the "basic structure" to those governed by "legally enforceable" rules, ${ }^{7}$ thereby excluding many that ought to be included. If this claim can be sustained, then even the view that judgments about institutional rules fall within the domain of distributive justice - a view central to the Rawlsian doctrine of "the basic structure as subject" - is open to criticism as too narrowly drawn.

What is the basis for Cohen's claim that the Rawlsian "basic structure" can be identified with the "legally coercive structure"?" A curious feature of the case Cohen presents is that he does not think this claim has a straightforward exegetical basis in what Rawls actually says about the "basic structure." Scrutiny of these passages - and Cohen devotes a good deal of attention to their interpretation - makes it clear that Rawls is not

\footnotetext{
${ }^{6}$ Recent discussions of the Cohen-Rawls debate include: Liam Murphy, "Institutions and the Demands of Justice" (Philosophy and Public Affairs 1998); David Estlund, "Liberalism, Equality, and Fraternity in Cohen's Critique of Rawls" (Journal of Political Philosophy 1998); Michael Titelbaum, "What Would a Rawlsian Ethos of Justice Look Like?" (Philosophy and Public Affairs 1998); Thomas Pogge, "On the Site of Distributive Justice: Reflections on Cohen and Murphy" (Philosophy and Public Affairs 2000); A.J. Julius, "Basic Structure and the Value of Equality" (Philosophy and Public Affairs 2003); Arash Abizadeh, "Cooperation, Pervasive Impact, and Coercion: On the Scope (not Site) of Distributive Justice" (Philosophy and Public Affairs 2007); Samuel Scheffler, "Is the Basic Structure Basic?" (in Christine Sypnowich, ed., The Egalitarian Conscience: Essays in Honour of G. A. Cohen 2008); and Seanna Shiffrin, "Incentives, Motives, and Talents," (Philosophy and Public Affairs 2010). See also Alistair M. Macleod, "G.A. Cohen on the Rawlsian doctrine of the basic structure as subject," Social Philosophy Today Vol 26, 2011.

${ }^{7}$ Rescuing Justice and Equality, footnote on p. 133. (See K.C. Tan, "Justice and Personal Pursuits," The Journal of Philosophy 101 (2004), p. 346.)

${ }^{8}$ The legal rules governing family and economic arrangements form a (perhaps rather small) sub-class of the rules that structure relationships within the family and the economy.
} 
unambiguously committed to limiting the institutions that belong to the "basic structure" to those governed by legally enforceable rules. ${ }^{9}$ On the contrary, Cohen recognizes that Rawls oscillates between identifying the "basic structure" with the "legally coercive" structure and conceiving of it more broadly as comprising all those social institutions that have a major impact on the distribution of "primary goods" across society. ${ }^{10}$ In face of this ambiguity in key passages, Cohen might have opted for a charitable interpretation instead of saddling Rawls with commitment to the much narrower ("legally coercive structure") account - especially since a restrictive construal rules out the applicability of principles of distributive justice both to a society's family arrangements and to the (nonlegal) rules that govern much of its economic life.

How, then, does Cohen argue that Rawls is more fundamentally committed to this narrower account? The argument is that Rawls is committed to drawing a sharp distinction between the rules that constitute and regulate the functioning of the institutions which belong to the basic structure and the everyday actions of the individuals who are subject to these rules, and that this distinction breaks down once we cross the line that divides legally enforceable institutional rules from other institutional rules (like those governing family arrangements). Whereas the personal choices of the members of a society can be at odds with legally enforceable institutional rules without the very existence of the rules being undermined, in the case of institutions like the family, the rules that shape everyday family interaction cannot be so much as identified independently of the day-to-day choices family-members make in compliance with them. The idea seems to be that legally enforceable rules are legislated into existence and remain "on the books" (so to speak), awaiting application by judges and administrators, whether or not there is a high level of compliance with them on the part of those who are subject to them. By contrast, the rules that serve to constitute such social institutions as the family can only be identified by reference to the patterns of behavior exhibited by family members. $^{11}$

However, Cohen's argument that Rawls is committed to a narrow (merely "legal") construal of the basic structure despite some of his more expansive remarks is fragile. The claim that only legal institutions qualify for inclusion in the basic structure because only such institutions permit a reasonably sharp distinction between the conditions under which rules can be said to exist and the conditions under which there is general compliance with such rules on the part of the individuals subject to them overlooks the many examples of institutional rules which, though not legally enforceable, do not differ from legally enforceable rules in this respect. Just as legally enforceable rules can be misapplied by those charged with their administration - the police, or lawyers and judges

\footnotetext{
${ }^{9}$ For this broader interpretation, see, e.g., Rawls, A Theory of Justice (1971), pp. 6-7

${ }^{10}$ If You're an Egalitarian, How Come You're So Rich?, pp. 129-130

${ }^{11}$ Rescuing Justice and Equality, pp 132-140
} 
- so too in the case of such institutions as universities, in which a variety of rules regulate the admission of students and the appointment and promotion of faculty and staff, administrative officers can misapply the rules without the very existence of the rules being in jeopardy. It may be objected that the existence of the rules is endangered if a pattern of administrative disregard for them comes to be established. There's obviously something to this objection, difficult though it may be to specify just how much systematic misapplication of the rules there has to be before they become a "dead letter." However, a precisely parallel point can be made about legally enforceable rules. They too will cease to exist - become a "dead letter" - if the relevant authorities, systematically and consistently, refuse or fail to apply them.

Even in the case of institutions belonging to "the informal structure" of a society governed by rules that exist in virtue of some social convention or social consensus - it isn't true that no distinction can be drawn between the conditions under which the rules can be said to exist (as part of a society's "informal structure") and those under which there is general conformity to the rules among the members of a society to whom they apply. Conventions governing family arrangements exist even if there happens to be something (significantly) short of general conformity to them on the part of family members. Just as we can ask how far those to whom legal rules apply generally adhere to them in practice, so too we can ask, in the case of the conventions governing family arrangements, how far family members generally adhere to them in practice.

Whether or not Rawls's account of the basic structure makes it easy for such institutions as the family to be represented as belonging to the basic structure, they cannot be said not to belong merely because the rules that regulate their operation aren't legally enforceable rules. The feature Cohen represents legally enforceable institutional rules as having - viz. that they permit a (sharp) distinction to be drawn between questions about their existence and questions about the degree to which individuals who are subject to their authority choose to comply with them - is not a uniquely identifying feature. It doesn't serve to mark them off from the rules that regulate the operation of such social institutions as the family or what Cohen calls a society's "informal structure."

Questions about precisely which institutions are amenable to assessment from the standpoint of distributive justice are, of course, questions to which narrower and broader answers can be supplied. Cohen thinks that Rawls's view of the domain of distributive justice is too narrow since it (allegedly) excludes all social institutions except those governed by legally enforceable rules. Unclear though it may be, at the margin, how widely, in the event, Rawls (or Cohen) may want to demarcate these boundaries - and Cohen's view might well be more expansive than Rawls's - Cohen's argument doesn't show that Rawls' view is, in this respect, indefensibly narrow. From a Rawlsian perspective such institutions as the family may well qualify as part of the domain of distributive justice. The rules governing family arrangements - even if (as Cohen claims) they enjoy the status of rules only because they are sustained by nothing more than social 
convention or social consensus - may well be amenable to assessment from the standpoint of distributive justice. ${ }^{12}$

\section{Individual Conduct and the Domain of Distributive Justice}

Cohen sometimes gives the impression that for Rawls principles of distributive justice apply only to "the basic structure" of society and therefore have no bearing on the personal choices made by individuals in everyday life. For example, as noted, Cohen writes that whereas in his own view "both just rules and just personal choice within the framework set by just rules are necessary for distributive justice," Rawls's view is that "distributive justice and injustice are features of the rules of the public order alone." (Italics supplied.) ${ }^{13}$

It would, however, be a mistake to suppose that judgments about individual conduct are simply excluded by Rawls from the domain of distributive justice and a mistake to think that Cohen attributes such a view to him. A more careful examination of Rawls's position - and of the target Cohen sets himself in his critique of Rawls - reveals at least three ways in which Rawls recognizes such judgments as judgments which must be made, at least indirectly, in the light of considerations of distributive justice.

First, Rawls recognizes that in the application to particular cases of the institutional rules that satisfy principles of distributive justice, it is individuals who make the necessary decisions. The decisions of public officials -- all those individuals whose job it is to administer institutional rules - are thus indispensable to the implementation of principles of distributive justice.

Second, the institutional rules officials are required to administer also generally impose obligations on members of society who occupy no administrative position. Sometimes, the rules require the ordinary members of a society to act in specified ways as when they are required to file an income tax return every year or to inform the health authorities if they contract a communicable disease. Sometimes, the rules confer rights on all members of society, which all are under an obligation not to violate. Provided the institutional rules which are the immediate source of the duties and rights of members of the public at large are rules that satisfy principles of distributive justice, judgments about the actions individuals perform when they either carry out their duties or violate the rights of others must be allowed to count as judgments we make by appeal to considerations of distributive justice - indirect though the appeal may be.

\footnotetext{
${ }^{12}$ In his "The Idea of Public Reason Revisited" (Collected Papers, ed. Samuel Freeman, Harvard University Press, 1999, pp. 573-615), Rawls writes: "The family is part of the basic structure, since one of its main roles is to be the basis of the orderly production and reproduction of society and its culture from one generation to the next." (op cit, p. 595)

${ }^{13}$ If You're an Egalitarian, How Come You're So Rich?, pp. 3-4
} 
Third, all the members of a democratically organized society are under a standing obligation, as citizens, to participate in the political life of the society with a view to ensuring that institutional arrangements are so structured as to secure the adequate implementation of principles of distributive justice. Thus, the decisions individuals make when they vote, join political parties, stand for public office, or participate in movements for social change are amenable to assessment from the standpoint of distributive justice.

Rawls's view of the domain of distributive justice cannot, then, be represented as unduly narrow on the ground that he excludes judgments about the justice of individual actions. The sharp opposition Cohen sometimes posits between Rawls's doctrine of the "basic structure as subject" and his own view that people's "personal choices" are also assessable from the standpoint of distributive justice gives the impression that this is part of his critique of what Rawls says about the domain of justice, but it is a mistake to suppose that Cohen accuses Rawls of this kind of narrowness.

Nevertheless, Cohen levels a similar charge against Rawls. He does think Rawls takes too narrow a view of the personal choices that qualify for assessment from the standpoint of distributive justice. The judgments about such choices Rawls recognizes form a mere sub-class of the judgments that ought in Cohen's view to be included in the domain of justice.

\section{Choices “Within" Institutional Rules and the Domain of Distributive Justice}

Although Cohen recognizes that Rawls's view doesn't preclude the raising of questions of distributive justice about certain choices individuals make in daily life, he insists that Rawls wrongly exempts certain other choices individuals make -- "within" the rules of the (Rawlsian) "basic structure"-- from scrutiny in the light of principles of distributive justice. ${ }^{14}$ The difficulty is to see both (1) what sorts of choices these are, and (2) why there is a difference of view, between Rawls and Cohen, about their status.

(1) It's important to be clear about the force of the distinction between the choices that Rawls thinks can be assessed from the standpoint of distributive justice and those that cannot.

What do choices to which the rules of the (Rawlsian) basic structure are applicable have in common? They are choices that the rules of the basic structure either require or forbid people to make. Principles of distributive justice are indirectly applicable to all such choices: the principles have a direct application to the rules that regulate the making of these choices (which is why the rules belong to a just "basic structure") and consequently they apply indirectly to these choices. When people conform to the rules of

${ }^{14}$ If You're an Egalitarian, How Come You're So Rich?, p. 148 
a just basic structure, they can be said to be acting justly; when they violate these rules, they are acting unjustly.

An assumption underlying this view has an interesting implication. The assumption, of course, is that to characterize a choice as "just" is to view it as required by a just institutional rule (and thus as indirectly required by principles of distributive justice) and that to characterize a choice as "unjust" is to view it as forbidden by a just institutional rule (and thus as forbidden indirectly by principles of distributive justice). The implication is that when the alternatives between which people make their choices are neither required nor forbidden by just institutional rules (and therefore by the principles of distributive justice that underpin the rules), the choices are neither "just" nor "unjust": they are "left open" by the rules of the basic structure.

When Cohen charges that some personal choices are wrongly exempted by Rawls from assessment by reference to principles of distributive justice, he must be taken to be referring to choices "left open" by the rules of the basic structure: it is these he frequently refers to as choices "within" the basic structure.

However, Cohen does not think that whenever people make choices "left open" by the basic structure they are making choices that are either required or forbidden by principles of justice. If this were the case, then - in Cohen's view - all the choices people make would be amenable to assessment from the standpoint of principles of distributive justice: some would be required or forbidden by the institutional rules belonging to a just basic structure and the rest required or forbidden by direct application of the principles of distributive justice that underpin a just basic structure.

How, then, does Cohen draw a distinction within the class of choices "left open" by the rules of the basic structure, between those that are and those are not subject to assessment by appeal to considerations of distributive justice? The short answer is that the distinction has to be drawn in the light of what he says about the "personal prerogative" people have to make some of the choices "left open" by the rules of a just basic structure without reference to principles of distributive justice.

However, this account isn't developed in detail. Consequently, it's a matter of conjecture how often - or seldom - people can invoke a personal prerogative when making choices "left open" by the rules of the basic structure. The larger the class of choices covered by a personal prerogative proves to be, the smaller the class will be of the choices left open by the rules of the basic structure to which Cohen holds considerations of distributive justice apply -- and the smaller the difference in practice will then be between Cohen's and Rawls's view of the domain of distributive justice.

(2) Whether the class of personal choices "within" the rules of the basic structure to which principles of distributive justice are thought by Cohen to have an application is a large or a small class, why do he and Rawls disagree about whether they are possible subjects of judgments of distributive justice? The reason is that they are at odds about 
whether principles of distributive justice are ever directly applicable to the choices people make. Rawls holds (in Cohen's view) that these principles apply directly only to the rules of the basic structure and that their application to the choices people make when they obey or flout these rules is therefore indirect: the choices are just or unjust only because they can be assessed by appeal to institutional rules to which principles of distributive justice are directly applicable. Cohen's position, by contrast, is that principles of distributive justice have both an indirect and a direct application to the choices people make. The application is indirect when they choose to conform to (or violate) the rules of a just basic structure, because the justice of these rules has first to be determined by appeal to principles of distributive justice. However, principles of distributive justice also have a direct application to choices "left open" by the rules of a just basic structure provided these are choices that are (a) neither required nor forbidden by these rules and (b) not covered by a personal prerogative that exempts them from scrutiny in the light of principles of distributive justice.

\section{Personal Choices, Institutional Rules and Justice in Distribution}

If personal choices "left open" by the rules of the basic structure and not protected by a personal prerogative are in Cohen's view choices that must be made in the light of considerations of distributive justice -- and if the exclusion of judgments about these choices from the domain of justice is a principal source of Cohen's complaint that Rawls takes too narrow a view of this domain - Cohen owes us an account of how precisely the relevant "considerations of justice" are brought to bear on making such choices.

There are three possibilities for which there is (some) support. ${ }^{15}$ (1) First, the inclusion in the domain of justice of the judgments about the justice of "personal choices" that Cohen says Rawls excludes is to be effected by adopting a broader view than Cohen alleges Rawls is prepared to take of the institutions that belong to the so-called "basic structure" of society. If such a broader view is adopted and institutions like the family are counted among those to which principles of justice are applicable, then personal choices constrained by the rules that regulate the operation of these (additional) institutions can be represented as choices individuals make (at least indirectly) in the light of considerations of justice, despite the fact they are choices "left open" by the rules of the basic structure when it is identified with the "legally coercive" structure. (2) Second, choices "left open" by the rules of the basic structure are choices individuals make when their behavior is governed by an "ethos" of distributive justice - where by "ethos" Cohen

\footnotetext{
${ }^{15}$ If You're an Egalitarian, How Come You're So Rich? (Lectures 8, 9, and 10), and Rescuing Justice and Equality (Chapter 3)
} 
means, roughly, a settled disposition to do whatever justice requires. ${ }^{16}$ (3) The third possibility is that choices "left open" by the rules of the (Rawlsian) basic structure must be made by direct appeal to principles of distributive justice without the mediation of institutional rules of any kind.

(1) The first of these accounts reflects an important strand in Cohen's critique: Cohen does object to the Rawlsian doctrine of "the basic structure as subject" on the ground that it embodies too narrow a view of the kinds of institutional arrangements to which principles of distributive justice are applicable. But the central question to which Rawls and Cohen (are said by Cohen to) return different answers there is whether judgments about the justice of institutions and institutional rules are more diverse than the Rawlsian doctrine of the basic structure would allow if the basic structure is identified with the "legally coercive" structure. Here, the question is whether personal choices "left open" by the rules of the basic structure are choices about which judgments of justice can be made. Of course, extending the range of institutions and institutional rules to which principles of justice are applicable has implications for what must be said about the justice of the choices individuals make in situations in which institutional rules have an acknowledged application. Thus, just institutional rules that are not legally enforceable do generate justice-based requirements and prohibitions for the individuals subject to them and these are neither required nor forbidden by the rules of the "coercive basic structure." However, although the choices people make when they comply with or breach these requirements and prohibitions are neither required nor forbidden by the coercive basic structure, they don't count as “choices within just rules" if, as in Cohen's characterization, the personal choices Cohen thinks, against Rawls, ought to be included in the domain of justice are choices "left open" by the rules of the basic structure.

(2) The trouble with the second view -- that the role played by an "ethos" of justice helps explain how personal choices "left open" by institutional rules are to be made in the light of considerations of justice -- is that we need to be given a more fundamental account of what the rationale is for the particular dispositions individuals are deemed to have when their conduct is said to be regulated by such an "ethos." No coherent account can be given of the disposition to make just choices if it takes no account of the fact that the primary application of principles of distributive justice cannot -- logically "cannot" -be to "dispositions." We can identify the disposition to act justly or to make just personal choices only by reference to principles of justice whose primary application is to things other than dispositions - that is, to the actions or choices that flow from the dispositions

\footnotetext{
${ }^{16}$ If You're an Egalitarian, How Come You're So Rich? (p.128), where he calls it "a structure of response lodged in the motivations that inform everyday life."
} 
rather than to the dispositions themselves. For example, if we say of actions or choices of type alpha that they are actions or choices which exemplify the disposition to act or choose justly, this is informative only because we can specify, independently, what makes actions or choices of type alpha "just." So when Cohen claims, against Rawls, that there are personal choices individuals are under an obligation of justice to make even though this obligation is not imposed by just institutional rules, and even though, consequently, the rationale for these choices must be independent of the justice of institutional rules, the choices can't be said to be just (when they're just) because they're motivated by an ethos of justice. The relevant justice considerations must be brought to bear in the first instance on choices: only in a derivative, indirect way, through application to choices that manifest the disposition, can the disposition itself be characterized as just.

(3) The third account goes some way towards explaining how judgments about the justice of the personal choices "left open" by the rules of the basic structure can be made without appeal either to institutional rules or to an ethos of justice. Principles of distributive justice that enable us, in their application to institutional rules, to make judgments about the justice or injustice of these rules can also be applied directly to some of the choices people make and this holds the key to our ability to pronounce on the justice or injustice of these choices without either subsuming the choices under institutional rules that have been vetted by the application of principles of justice to them or representing them as flowing from an ethos of justice.

What else is involved in applying principles of distributive justice directly to the personal choices "left open" by institutional rules? An important passage in Cohen's writings helps point the way to an answer. When he is setting the stage for discussion of the Rawlsian doctrine of the "basic structure as subject," he presents what he calls "a background point" about the difference between Rawls and himself "with respect to the site or sites at which principles of justice apply." He writes:

My own fundamental concern is neither the basic structure of society, in any sense, nor people's individual choices, but the pattern of benefits and burdens in society: that is neither a structure in which choice occurs nor a set of choices, but the upshot of structure and choices alike. ${ }^{17}$

Unlike Rawls, Cohen does not assign logical primacy, among judgments of distributive justice, to judgments about the institutional rules belonging to the basic structure but to judgments about states of affairs, understood as constituted by determinate distributions of the benefits and burdens of social life. Judgments about institutional rules are viewed as derivable from judgments about states of affairs because,

${ }^{17}$ Rescuing Justice and Equality, pp. 125-126 
and so far as, their implementation can be expected to contribute to a just distribution of the benefits and burdens of social life. This view of Cohen's about the primary 'site' of distributive justice provides the obvious answer to the somewhat puzzling question raised earlier about the rationale for Cohen's claim, against Rawls, that there are certain personal choices (made "within" the rules of the basic structure) that are assessable by direct appeal to principles of distributive justice, without the mediation of the institutional rules that belong to a just basic structure. The answer is that the choices in question can be characterized as "just" or "unjust" by asking whether or not they contribute directly to justice in the distribution of benefits and burdens. The claim that personal choices "within" the rules of the basic structure can be represented as just by direct appeal to the Difference Principle is thus tantamount to the claim that they contribute directly to maximization of the income and wealth of the worst off members of society. This view stands in contrast to Rawls's view because for Rawls - as Cohen interprets his position here - the Difference Principle applies directly only to the rules belonging to the basic structure and only indirectly to the choices people make through conformity to these rules. The Difference Principle cannot be invoked in support of judgments about the justice or injustice of the choices people make "within" the rules of the basic structure, because Rawls is committed to holding that such choices are neither required nor forbidden by these rules and that there is no other way (for example by direct invocation of the Difference Principle) that these choices could nevertheless be characterized as just or unjust. Cohen's view, by contrast, is that the choices people make

"within" the rules of the basic structure can be required or forbidden by the Difference Principle -- precisely because the Difference Principle can be applied directly to these choices, by asking whether they help to maximize the share of income and wealth of the worst off members of society. For Cohen, but not for Rawls, the Difference Principle has both an indirect application (to choices required by the rules that qualify for inclusion in a just basic structure) and a direct application (to some choices people make "within" these rules), and both of these applications can be rendered intelligible because it is states of affairs (constituted by determinate distributions of the benefits and burdens of social life) that are the most basic subjects of judgments of distributive justice. Choices required or forbidden by institutional rules that contribute to a just distribution of benefits and burdens are, for that reason, deemed just. Similarly, some choices people make "within" these rules contribute directly to a just distribution of benefits and burdens and are, for that reason, deemed just.

\section{Do Cohen and Rawls Disagree about the Status of Outcome-oriented Judgments of Justice?}

Cohen accords "primacy" within the domain of distributive justice to judgments about states of affairs, not to judgments about the justice of institutions. States of affairs are constituted by determinate distributions of the benefits and burdens of social life, 
distributions that are (for the most part $^{18}$ ) brought about by a society's institutions. The strikingly outcome-oriented ${ }^{19}$ posture he adopts places him at odds with the Rawlsian doctrine that it is judgments about institutional rules that are basic and that judgments about the states of affairs these rules help bring about are admissible judgments of distributive justice only because they are derivable from judgments of justice about the rules belonging to the basic structure. According to this merely "proceduralist" interpretation of Rawls's view, judgments about the justice of institutional outcomes can be accommodated only as derivative judgments of distributive justice.

Since Cohen reverses the order of dependence between judgments about rules and outcomes, it is surprising that his critique of the doctrine of the basic structure as subject does not exploit this difference by issuing a direct challenge to the Rawlsian dictum that the "primary" subjects of distributive justice are institutions. His critique of the Rawlsian doctrine of the basic structure as subject, while embodying complaints both about the narrowness of the Rawlsian "basic structure" and about the exclusion from the domain of distributive justice of (at least some) personal choices people make "within" the rules of the basic structure, fails to engage directly with the Rawlsian dictum that the "primary" subjects of judgments of distributive justice are institutions.

I want to argue that the dictum misrepresents the position Rawls is committed to taking about the relationship between justice-judgments about institutional rules and justice-judgments about institutional outcomes: there is in fact no deep disagreement between Cohen and Rawls about this structural feature of the domain of distributive justice. Both assign logical primacy to judgments about the justice of states of affairs.

Despite his sponsorship of the view that judgments about institutions are "primary" -which implies that judgments about the states of affairs institutional

\footnotetext{
${ }^{18}$ The qualification here allows for the role of personal choices "within" institutional rules in contributing directly to a just distribution of the benefits and burdens of social life.

${ }^{19}$ Whether an outcome-oriented account of judgments of distributive justice - an account, that is, that represents the application of "just" and "unjust" to institutions as deriving from their (primary) application to the states of affairs these institutions help to bring about - should be characterized as consequentialist depends on how "consequentialism" (as a term of art in philosophy) is to be understood. If, as is often the case, it is a label for the doctrine that the "right" (including the "just") is what contributes to "maximization of the good" - and in this use "consequentialism" and "utilitarianism" are often treated as more or less interchangeable terms - Cohen's outcome-oriented account is not consequentialist. If, however, the term is understood more broadly - as it is by Thomas Pogge in John Rawls: His Life and Theory of Justice (Oxford University Press, 1999, pp. 43-44) when he writes that "a moral criterion is consequentialist when it judges candidates solely by their consequences or effects" and that this "leaves entirely open which effects are morally relevant and how such morally relevant effects are to be scored" -- Cohen's account qualifies as consequentialist. So understood, it's a form of justice consequentialism because it holds that institutional outcomes can be characterized as "just" or "unjust" on the basis of direct application to them of principles of distributive justice.
} 
arrangements help to bring about are somehow derivative - Rawls's own principles of justice must be taken to apply in the first instance to states of affairs and only derivatively to institutional rules. The reason is that institutional arrangements that satisfy such principles as the Equal Liberty or Equal Opportunity principles can only be viewed as "just" because the distribution of the primary goods to which these arrangements contribute - the distribution of "freedom" and of educational and occupational "opportunity" -- is the (equal) distribution mandated by these (Rawlsian) principles of justice.

What about Rawls's Difference Principle? Does it too apply in the first instance to institutional outcomes and only derivatively to institutions? In support of a standard (merely "proceduralist") reading of the Difference Principle it is often pointed out that Rawls expressly claims in certain well-known passages that questions of economic distribution - the distribution of income and wealth-are to be handled as questions of "pure procedural justice" ${ }^{20}$ and that an economic distribution can be deemed just only if it is generated by economic decisions that conform to the rules of a just economic system, where these rules are just if in some direct way they satisfy the Difference Principle. An economic distribution brought about through adherence to the rules of a just economic system is represented as "just" whatever it is, precisely because it is a distribution generated by conformity to these rules. The justice of any given distribution of income and wealth is thus a function of the justice of the economic decisions that have generated it and these decisions, in turn, are just in virtue of their conformity to the rules of the economic system. The rules that give content and structure to a society's economic institutions can be seen to be just by the direct application of the Difference Principle. There is no independent criterion of the justice of an economic distribution.

On this merely "proceduralist" reading of the status of Rawls's Difference Principle, it would obviously be a mistake to attribute to Rawls the view that judgments about the states of affairs brought about by adherence to the rules governing the economic system provide the basis for judgments about the justice of these rules and the rule-grounded economic decisions that bring these states of affairs about.

Nevertheless, the view that questions of economic distribution can be handled as questions of "pure procedural justice" seems incompatible with Rawls's endorsement of the Difference Principle as the principle by reference to which the justice of economic distributions is to be determined. This is because the Difference Principle can only be applied indirectly to the assessment of the rules that give shape to an economic system. It is only by trying to ascertain whether adherence to the rules of a given economic system will typically generate a distribution of income and wealth across society as a whole that maximizes the income and wealth of the worst off members of society that a judgment can be reached about the justice, from the standpoint of the Difference Principle, of the

${ }^{20}$ John Rawls, A Theory of Justice, pp. 74-75 
rules themselves. ${ }^{21}$ The primary application of the Difference Principle has to be to the states of affairs that typically eventuate from the conformity of economic agents to the rules of a given economic system. It is consequently only derivatively that the rules themselves can be said to satisfy the Difference Principle. The content of the Difference Principle thus gives Rawls's account of economic justice a more outcome-oriented cast than seems to be permitted by his professed commitment to the handling of questions of economic distribution as questions of "pure procedural justice." Indeed, since the Difference Principle itself provides an "independent criterion" of the justice of an economic distribution, the question of just economic shares is in fact treated by Rawls as a question of (what he calls) "imperfect procedural justice." This is because, as Rawls himself puts it, "(t)he characteristic mark of imperfect procedural justice is that while there is an independent criterion for the correct outcome, there is no feasible procedure that is sure to lead to it." 22

That the problem of economic distribution is actually one of "imperfect procedural justice" can be confirmed both (1) by contrasting what Rawls says about justice in the distribution of income and wealth with a certain sort of libertarian version of Nozick's doctrine of economic justice and (2) by noting a respect in which the Difference Principle resembles the Utilitarian principle of utility-maximization.

(1) The instructive contrast here is between Rawls's view of economic justice and a rather specific version of libertarianism. This version has close ties to an important part of Nozick's "historical entitlement" account of distributive justice in that it follows Nozick in his insistence on the importance to justice in economic distribution of fully voluntary interaction between members of society in the economic domain. However, in making the voluntariness of economic interaction the centerpiece of their account of economic justice, defenders of this version of libertarianism represent the voluntary transactions principle as a "stand-alone" principle that does not need to be applied - in the way Nozick insists it does - in conjunction with another principle of justice, the principle of justice in the (initial) "acquisition" of economic assets. Whereas Nozick holds that a market-determined economic distribution is just only if it can be established both (a) that the pre-transaction distribution of economic assets was a just distribution (by the principle of "justice in acquisition"), and (b) that market participants have interacted over time in a fully voluntary manner (in line with the principle of "justice in transfer"), ${ }^{23}$ libertarians (of the sort in question) dispense with requirement (a) and represent (b) as a sufficient condition of the justice of market-determined distributions of

\footnotetext{
21 This is confirmed by the account given by Thomas Nagel in his contribution to The Cambridge Companion to Rawls, edited by Samuel Freeman (Cambridge University Press, 2003), p. 71.

${ }^{22}$ John Rawls, A Theory of Justice, pp. 74-75

${ }^{23}$ Robert Nozick, Anarchy, State, and Utopia (Basic Books, 1974), pp. 150-153
} 
economic assets. While this version of libertarianism is much more difficult to defend than Nozick's doctrine - given the importance of requirement (a) to the elaboration of an account of economic justice along "historical entitlement" lines - it has an interesting feature, in that it would enable the problem of just economic distribution to be handled as a problem of "pure procedural justice." This is because the principle of voluntary transactions in the unqualified version that is the hallmark of this sort of libertarianism can be applied without any (even oblique) reference to the distribution of economic and other goods that is effected over time by voluntary market interaction. The voluntary transactions principle (in its unqualified version) is satisfied when market interaction satisfies a single condition - that is, when market participants buy, sell, or exchange the goods and services they own or control in a fully voluntary manner. There is no call for scrutiny of the distribution of economic assets brought about by the transactions to which market participants are parties. Whatever the consequences of these transactions happen to be - and it is immaterial whether or not the consequences were intended, or foreseen, or foreseeable - they have no absolutely no bearing on whether the transactions themselves were voluntary. For theorists for whom satisfaction of the voluntariness requirement is the only condition that must be fulfilled for market-generated economic distributions to be declared to be just, these distributions can be declared to be just whatever they are. Judgments about the justice or injustice of states of affairs - states of affairs constituted by determinate economic distributions, for example - can thus be represented by libertarians of this kind as derivative judgments of distributive justice. An economic distribution is just if and only if the economic transactions that have brought it about were fully voluntary. Since the justice of economic transactions can be determined -- by appeal to the voluntary transactions principle - without any reference to the outcome of these transactions, the problem of justice in economic distribution can be handled as a problem of "pure procedural justice."

Things are very different for Rawls, given his sponsorship of the Difference Principle as his principle of economic justice. Unlike the (unqualified) voluntary transactions principle, its content requires attention to the consequences of economic interaction. The principle cannot be given any determinate content without foregrounding questions about the distributive upshots of alternative ways of structuring the rules that govern economic interaction. For the rules of an economic system - the rules to which market participants are required to conform - to satisfy the Difference Principle, they must be rules that contribute to maximization of the income and wealth of the worst off members of society. The problem of just economic distribution must thus be seen to be a problem of "imperfect" procedural justice, not a problem of "pure" procedural justice.

(2) If we set aside our surprise at Rawls sometimes indicating that a "pure procedural justice" approach to questions of economic justice should be adopted, there is 
really nothing surprising about Rawls's doctrine of economic justice having to be characterized as outcome-based. Indeed, the Difference Principle is strikingly similar to the principle of utility-maximization in this respect. That Utilitarianism is an outcomeoriented normative doctrine is uncontroversial because it represents the moral defensibility of institutional rules as a function of the contribution these rules (can be expected to) make to the bringing about of states of affairs in which social "utility" is maximized. Although as a critic of Utilitarianism Rawls isn't prepared to link defensible principles (including the principles of "justice as fairness") to maximization of "social utility," his Difference Principle calls for (economic) institutional arrangements to maximize the income and wealth of the worst-off members of society. For Utilitarians and Rawls alike, the criterion of the moral defensibility of economic institutions is the role they play in bringing about a specific kind of outcome: maximization of social benefit for society as a whole in the one case, maximization of the income and wealth of the worst off members of society in the other. If Utilitarianism can be classified as an outcomeoriented doctrine, so too must Rawls's doctrine of economic justice.

Do Cohen and Rawls disagree, then, about the status of outcome-oriented judgments of justice? They agree that judgments about the justice of the states of affairs brought about by a society's institutional arrangements can be made. They agree, consequently, about such judgments falling within the boundaries of the domain of distributive justice. However, they disagree about the relationship that obtains between judgments about the justice of institutional rules and judgments about the justice of institutional outcomes -- if Rawls can be taken at his word when he assigns logical primacy to judgments about institutional rules. However, the Rawlsian dictum that the "primary" subjects of judgments of distributive justice are institutions (and not the states of affairs in which they eventuate when implemented) is inconsistent with the content of Rawls's own principles of distributive justice, including the Difference Principle. Given the reasonableness of "resolving" this inconsistency by saving the substance of the doctrine of "justice as fairness," the conclusion that ought to be drawn is that, at bottom, there is really no difference between Cohen and Rawls. They must be taken to agree that judgments about distributive outcomes are logically more fundamental than those about the institutions that belong to a society's "basic structure." Despite its "proceduralist" façade, Rawls's own theory - "justice as fairness" - is outcome-oriented in substance.

\section{Conclusion}

On the question of the boundaries and contours of the domain of distributive justice - about the sorts of judgments that count as judgments of distributive justice and about their logical interconnections - the surface differences between the views of Cohen and Rawls conceal important underlying similarities. They agree that principles of distributive justice can be applied to the following: institutional rules (including those 
that belong to the "basic structure" of society), individual conduct (in particular the actions performed, or the decisions made, when individuals obey or disobey, apply or misapply, just institutional rules), the attitudes and dispositions of individuals (when these motivate them to help realize justice in society), and states of affairs (where these are constituted by determinate distributions of the benefits and burdens of social life). They also agree -- if surface disagreement generated by the Rawlsian dictum that the "primary" judgments of justice are judgments about institutions is set aside -- that a certain logical priority, among judgments of distributive justice, must be accorded judgments about the justice or injustice of states of affairs. Judgments about the justice or injustice of people's attitudes and dispositions, their actions and decisions, and judgments about the justice of a society's institutions (including those that belong to the "basic structure") are all indebted, directly or indirectly, to judgments about the justice or injustice of the states of affairs constituted by determinate distributions of the benefits and burdens of social life.

Where do they disagree? It might be thought that they disagree about how broadly the institutions belonging to the "basic structure" should be conceived. If it were only institutions governed by legally coercive rules that qualified, in Rawls's view, for inclusion in the basic structure, Cohen's insistence that institutions governed by noncoercive rules (rules established and maintained by social consensus, for example) ought also to be included would point to an important difference between them. However, despite the fact that he sometimes targets the narrower view, Cohen recognizes that there is textual evidence for Rawls's acceptance of the broader view.

There is firmer basis for thinking that they do not to see eye to eye about whether people's personal choices within the rules of a just basic structure can be characterized as "just" or "unjust" - that is, about whether such choices are either required or forbidden by principles of distributive justice. Rawls (in Cohen's view) is committed to excluding judgments about personal choices of this sort from the domain of distributive justice because (a) principles of distributive justice can be applied to matters of individual conduct and choice only indirectly (by reference to the institutional rules to which these principles have a direct application), and (b) personal choices "within" institutional rules are neither "just" (required by these rules) nor "unjust" (forbidden by these rules). The truth of (b) can be taken for granted: indeed it is true by definition, given Cohen's (stipulative) characterization of choices "within" the rules of the basic structure as choices these rules neither require nor forbid. Establishing the truth of (a) is altogether more complicated, and I haven't tried in this paper to determine whether it's true or not. Whether (a) can in the end be ascribed to Rawls depends, in large part, on whether Rawls thinks justice can be fully achieved "by structural means." ${ }^{24}$ For "structural means" to

\footnotetext{
${ }^{24}$ In an interesting paper of Bertrand Russell's ("Reflections On My Eightieth Birthday," in Portraits from Memory, and Other Essays, Allen \& Unwin 1956), he nicely anticipated the view that justice in society can
} 
suffice for the achievement of justice in society, two very demanding conditions would have to be fulfilled. First, a society's institutional rules would have to be in conformity with principles of distributive justice. Second, these rules would have to be consistently obeyed or observed by all to whom they apply. Cohen clearly thinks that justice in society cannot be reliably achieved by merely "structural means." He takes this view not merely because the two "structural" conditions cannot in practice be fully met, though he of course recognizes how crucial it is to the achievement of justice in society for its institutional rules to satisfy principles of distributive justice and for those who are subject to these rules to obey them consistently. He also recognizes that the cause of justice may sometimes need to be advanced by choices people have a justice-based obligation to make even though the obligation has its source, not in institutional rules that satisfy principles of distributive justice, but in the principles themselves.

To see the obligation to make certain choices "within" the rules of the "basic structure" as grounded in principles of distributive justice is tantamount to recognizing that even judiciously articulated institutional rules can never be fine-grained enough to capture all the requirements of justice in particular situations. These requirements can only be identified, in situations not adequately "covered" by just institutional rules, by direct appeal to the principles of justice that underpin the rules. Thus, when this sort of appeal has to be made to the Difference Principle to determine what is involved in making personal choices "within" the institutional rules that satisfy the Difference Principle, the choices in question are choices that would make a direct contribution to maximizing the share of income and wealth of the worst off members of society.

To the question how Cohen's view of the boundaries and contours of the domain of distributive justice compares with Rawls's view, the general answer, then, is that the similarities are more striking than the differences. This has gratifying implications for the larger - and more interesting -- question how, and how far, their substantive doctrines of distributive justice differ, since it means that, on most issues, such disagreements as there may be can generally be clearly articulated. If, here and there, their substantive views are at odds, at least they are largely at one about what the crucial questions are.

only be secured if, in addition to establishing just institutions, the members of a society are prepared to be governed, in many of the "personal choices" they make, by principles of distributive justice. Russell wrote: "There are those who hold that everything depends on institutions, and that good institutions will inevitably bring the millennium. And, on the other hand, there are those who believe that what is needed is a change of heart, and that, in comparison, institutions are of little account. I cannot accept either view. Institutions mould character, and character transforms institutions. Reforms in both must march hand in hand." 


\section{References}

Cohen G.A. "Where the Action Is: On the Site of Distributive Justice," Philosophy and Public Affairs 26 (1997)

Cohen, G.A. If You're An Egalitarian, How Come You're So Rich? (Harvard University Press, 2000)

Cohen, G.A. Rescuing Justice and Equality (Harvard University Press, 2008)

MacLeod, Alistair M. "G.A. Cohen on the Rawlsian doctrine of the basic structure as subject," Social Philosophy Today 26 (2011)

Nagel, Thomas. "Rawls and Liberalism," in Samuel Freeman (ed.), The Cambridge Companion to Rawls (Cambridge University Press, 2003)

Nozick, Robert. Anarchy, State, and Utopia (Basic Books, 1974)

Pogge, Thomas. John Rawls: His Life and Theory of Justice (Oxford University Press, 1999)

Rawls, John. A Theory of Justice (Harvard University Press, 1971)

Rawls, John. Collected Papers, ed. Samuel Freeman (Harvard University Press, 1999)

Russell, Bertrand. "Reflections On My Eightieth Birthday," Portraits from Memory, and Other Essays (Allen \& Unwin, 1956)

Tan, K.C. “Justice and Personal Pursuits," The Journal of Philosophy 101 (2004) 